\title{
Efficacy and Safety of Curcuma longa L: Relevant Results for Cancer Treatment
}

\author{
Erika Cosendey Toledo De Mello Peixoto ${ }^{1}$, Fernando Raimundo Silva ${ }^{1}$, Amanda Figueiredo ${ }^{1}$, \\ Filipe Oliveira Granero ${ }^{2}$, Célia Cristina Malaguti Figueiredo², Luciana Pereira Silva ${ }^{3}$ and \\ Regildo Márcio Gonçalves Da Silva ${ }^{2,4^{*}}$
}

${ }^{1}$ Department of Animal Production, Laboratory of Animal Parasitological Control in Agroecological and Organic Production Systems, State University of Northern Paraná (UENP), Brazil

${ }^{2}$ Institute of Chemistry, São Paulo State University (UNESP), Brazil

${ }^{3}$ Fundação Educacional do Município de Assis (FEMA), Assis, São Paulo, Brazil

${ }^{4}$ Department of Biotechnology, Laboratory of Herbal Medicine and Natural Products, São Paulo State University (UNESP), Brazil

\begin{abstract}
Cancer represents an important public health challenge, and its occurrence has been increasingly observed at human and veterinary medicine. However, despite of the significant results published by the scientific community, the use of medicinal plants for cancer treatment is not properly widespread. Thus, considering that Curcuma longa Linn. has demonstrated an important antitumor activity, the objective of this study was to present the main results of in vitro and in vivo studies. The anticancer activity of turmeric was found by the capability to induce apoptosis, reduce metastatic potential and inhibiting different tumor types of proliferation. In addition, other activities such as immunomodulatory, anti-inflammatory, and the inhibitory effect on modulating proteins of drug resistance are relevant for tumor therapy. Therefore, the results demonstrated by in vitro and in vivo studies showed that $C$. longa presents important evidence of prophylactic and curative effect for cancer treatment.
\end{abstract}

\section{Keywords}

Antitumor, Medicinal plants, Neoplasms Curcuma longa, Turmeric

\section{Introduction}

Cancer represents an important public health challenge, and its occurrence has been increasingly observed in both human and veterinary medicine [1,2]. Several modalities of natural medicine have been used as complementary therapy in oncological treatment, emphasizing the use of medicinal plants [3]. The diffusion of these natural therapies among cancer patients is mainly due to the dissatisfaction with the results of conventional medicine and the ability to reduce the usual side effects of chemotherapy and radiotherapy [3]. In addition, the affinity for the use of natural products and the search for lower cost treatments are considered [4].

The use of medicinal plants accentuated from the 90's, mainly due to aspects as safety, effectiveness, and low cost in comparison to chemical drugs. However, despite of the significant results published by the scientific community, an important obstacle to adequate use of medicinal plants is the fact that this knowledge is not properly widespread. In cases that cancer patients are not attended in their request regarding the use of medicinal plants, it is often observed the independent use of these plants by themselves. So, the most patient adept at medicinal plants obtains the information from popular knowledge, using them in oncological treatments in an empirical way [5].

Empirical use may be detrimental to the health and

\footnotetext{
*Corresponding author: Regildo Márcio Gonçalves da Silva, Department of Biotechnology, Laboratory of Herbal Medicine and Natural Products, Faculty of Sciences, Humanities and Languages, São Paulo State University (UNESP), Assis, São Paulo, Dom Antonio Avenue 2100, 19806-900, Brazil, Tel: +5518-33025800

Accepted: February 12, 2022

Published online: February 14, 2022

Citation: Peixoto ECTDM, Silva FR, Figueiredo A, et al. (2022) Efficacy and Safety of Curcuma longa L: Relevant Results for Cancer Treatment. J Hortic Sci Res 5(1):175-183
} 
efficacy of cancer treatment and may lead to hepatotoxicity, nephrotoxicity, and cardiovascular toxicity [6]. Therefore, the development and dissemination of research related to the use of medicinal plants in oncology is justified not only by the growing interest but also especially by the need to sensitize health professionals to the possibility of effective complementary therapy. Thus, considering that $C$. longa has been shown to present an important antitumor potential, the objective of this study was to discuss the main relevant results of in vitro and in vivo studies about the antitumor activity of Curcuma longa Linn.

\section{Review Methodology}

The studies presented in this review were identified through a literature review conducted on Google Scholar, Scielo, Medline and Science Direct. The key terms used were: Antineoplastic, antitumor, medicinal herbs, neoplasms, saffron and turmeric.

In spite of the intense effort on the conduction of research aimed to cancer therapies, many patients continue to receive an unfavorable prognosis. Thus, the effort for finding anticancer treatments with better efficacy and lesser side effects has been continued. This review was focused on the beneficial effects of $C$. longa for various types of cancer. The main findings of these results were also summarized and discussed.

\section{Historical Background}

\section{Compounds and antitumoral activity}

C. longa or zerdeçal, is also known as turmeric in Englishspeaking countries, jiang huang in eastern countries, and curcuma or saffron in latin-speaking countries. Belonging to the family Zingiberaceae, turmeric is herbaceous plant, perennial that present large and long leaves and ovoid rhizomes. It is native to India and southeast of Asia, but it is spread throughout Europe and America.

The turmeric anticancer activity was evidenced by the ability to induce apoptosis (Table 1) [7-16], inhibit proliferation of different tumor types and favor metastasis reduction (Table 2) [17-27].

Inhibitory effect against angiogenesis, growth factor receptors and cell adhesion molecules involved in tumor growth was associated to the potential to reduce metastasis. Curcuminoid compounds such as demethoxycurcumin, bisdemethoxycurcumin, and tetrahydrocurcumin were isolated from turmeric root. Among the commonly isolated curcuminoids, curcumin is the most abundant, highlighting that 13 curcuminoids with anticancer activity were described [28].

Comparing the cell growth inhibition effect by pure curcumin and turmeric methanolic extract, it was presented much more effective inhibition by curcumin (half maximal inhibitory concentration $\left.\left(I C_{50}\right)=41.69 \pm 2.87 \mu \mathrm{g} \mathrm{mL}^{-1}\right)$ than the turmeric methanolic extract $\left(I C_{50}=196.12 \pm 5.25 \mu \mathrm{g} \mathrm{mL}\right.$ $\left.{ }^{1}\right)[15]$. But factors such as tumor type $[7,29,30]$ and dosetime-dependent action [7,27,30-32] appear to interfere in anticancer activity.

Curcumin (2 $\mu \mathrm{M})$ decreased mesenchymal cell proliferation while cell death was detected only at $50 \mu \mathrm{M}$. Highly migratory cells decrease on migration speed and directionality about $50 \%$ and $40 \%$ when treated with 2 or $5 \mu \mathrm{M}$ of curcumin, respectively. In addition, the curcumin decreased cell adhesion with dose dependence, especially on tumor-derived spheroids [27].

Table 1: Induction of apoptosis by turmeric, its mechanisms of action, and their respective references.

\begin{tabular}{|c|c|c|}
\hline Mechanisms of action & Affection & References \\
\hline $\begin{array}{l}\text { reduction of anti-apoptotic Bcl-2 protein, and increase of pro- } \\
\text { apoptotic Bax protein (dose-dependent effect) }\end{array}$ & $\begin{array}{l}\text { Hepatoma (HepG2) and } \\
\text { breast cancer (MCF-7, MDA-MB-231) }\end{array}$ & YUE, et al. [7] \\
\hline $\begin{array}{l}\mathrm{Bcl}-2 \text { reduction, increase protein Bax and cell apoptosis by } \\
\text { activating the } \mathrm{PI} 3 \mathrm{~K} / \mathrm{Akt} \text {. }\end{array}$ & $\begin{array}{l}\text { Pulmonary carcinoma } \\
\text { (NCl-H460) }\end{array}$ & WU, et al. [8] \\
\hline $\begin{array}{l}\text { Reduction of } \mathrm{Bcl}-2 \text { and transcription factor STAT- } 3 \text { associated } \\
\text { with the cell cycle genes }\end{array}$ & Glioblastoma cells & SENFT, et al. [9] \\
\hline \multirow[t]{4}{*}{$\mathrm{Bcl}-2$ reduction } & $\begin{array}{l}\text { Metastatic melanoma (A375, FO1, Hs294T, } \\
1106 \text { MEL) }\end{array}$ & BILL, et al. [10] \\
\hline & Breast adenocarcinoma & IBRAHIM, et al. [11] \\
\hline & Cholangiocarcinoma & PRAKOBWONG, et al. [12] \\
\hline & $\begin{array}{l}\text { Thyroid cancer } \\
\text { (K1 cells) }\end{array}$ & SONG, et al. [13] \\
\hline $\begin{array}{l}\text { Kill SPC-A1 cells (high doses), apoptosis SPC-A1 cells (small } \\
\text { doses) }\end{array}$ & Cancer cells (HeLa) & SANTOS, et al. [14] \\
\hline Apoptosis and inhibition of cell proliferation & Hepatocellular carcinoma HepG2 cell lines & ABDEL-LATEEF, et al. [15] \\
\hline $\begin{array}{l}\text { Increased caspase- } 3 \text { activity, decreased } \mathrm{Bcl}-2 \text { and } \mathrm{PI} 3 \mathrm{~K} \text { protein } \\
\text { expression, and decreased the phospho }(\mathrm{p}) \text {-Akt protein } \\
\text { expression and activated miR-15a expression. }\end{array}$ & Laryngeal cancer cells & MOU, et al. [16] \\
\hline
\end{tabular}


Citation: Peixoto ECTDM, Silva FR, Figueiredo A, et al. (2022) Efficacy and Safety of Curcuma longa L: Relevant Results for Cancer Treatment. J Hortic Sci Res 5(1):175-183

Table 2: Antimetastatic and antiproliferative action by turmeric, its mechanisms of action, and their respective references.

\begin{tabular}{|l|l|l|}
\hline Mechanisms of action & Affection & References \\
\hline Inhibition Notch-1 transcription fator & Osteosarcoma cell lines & LI, et al. [17] \\
\hline Wnt pathway inhibition & Prostate cancer & LU, et al. [18] \\
\hline $\begin{array}{l}\text { Reduction in the expression of cyclin D1 (protein involved with } \\
\text { G1-S cell cycle) }\end{array}$ & Gastric cancer & CAI, et al. [19] \\
\hline $\begin{array}{l}\text { Inactivation of cyclin-dependent kinases (CDK), and increased } \\
\text { mRNA of inhibitory genes p21 and p27 }\end{array}$ & Pulmonary carcinoma (NCI-H460) & SAHA, et al. [20] \\
\hline $\begin{array}{l}\text { Inhibition of the cell cycle in phase G2/M } \\
\text { Inhibition of the production of three proteins (Tcf-4, CBP and } \\
\text { P300), related to Wnt transcription }\end{array}$ & $\begin{array}{l}\text { Colon cancer } \\
\text { (Rko and HCT116) }\end{array}$ & MUDDULURU, et al. [21] \\
\hline $\begin{array}{l}\text { Reduced expression of MMP-9 } \\
\text { (22rv1) }\end{array}$ & Breast cancer (metastasis) & TEITEN, et al. [22] \\
\hline $\begin{array}{l}\text { decrease in apoptotic sunburn cells, and decrease expression } \\
\text { of proliferation nuclear antigen (PCNA) }\end{array}$ & Skin cancer induced by ultraviolet radiation & TSAI, et al. [24] \\
\hline $\begin{array}{l}\text { inhibition of Notch-1 transcription factor (associated with } \\
\text { increased proliferation and tumor invasion) }\end{array}$ & Three osteosarcoma cell lines & LI, et al. [25] \\
\hline $\begin{array}{l}\text { Antiproliferative effects in SPC-A1 (in vitro and in vivo test) } \\
\text { Decrease adhesion, migration, and proliferation (in vitro and in } \\
\text { vivo test) }\end{array}$ & $\begin{array}{l}\text { Oral squamous cell carcinoma (OSCC), } \\
\text { fibroblast cell lines and xenograft model of } \\
\text { OSCC }\end{array}$ & CAMPOS, et al. [27] \\
\hline
\end{tabular}

Table 3: Anti-inflammatory and immunomodulatory activities presented by turmeric, its mechanisms of action, and their respective references.

\begin{tabular}{|c|c|c|c|}
\hline Activity & Mechanisms of action & Affection & References \\
\hline \multirow[t]{4}{*}{ Anti-inflammatory } & Stimulation enzymes caspases $3,8,9$ & $\begin{array}{l}\text { Hepatoma (HepG2) and } \\
\text { breast cancer (MCF-7, } \\
\text { MDA-MB-231) }\end{array}$ & YUE, et al. [7] \\
\hline & Activation of caspases & $\begin{array}{l}\text { Pulmonary carcinoma } \\
\text { (NCl-H460) }\end{array}$ & WU, et al. [8] \\
\hline & $\begin{array}{l}\text { NF- } \mathrm{KB} \text { inhibition associated with cyclooxygenase-2, } \\
\text { prostaglandin } \mathrm{E}_{2} \text {, and NO }\end{array}$ & Several cells & $\begin{array}{l}\text { BASNET; SKALKO- } \\
\text { BASNET [37] }\end{array}$ \\
\hline & $\begin{array}{l}\text { protective effect involved thymine dimer, PCNA, apoptosis, } \\
\text { transcription factors NF-KB, inhibition of COX-2, PGE2, NO, } \\
\text { and upregulation of p53 and p21/Cip1 to prevent DNA } \\
\text { damage and facilitate DNA repair }\end{array}$ & $\begin{array}{l}\text { Skin cancer induced by } \\
\text { ultraviolet radiation }\end{array}$ & TSAI, et al. [24] \\
\hline \multirow[t]{4}{*}{ Immunomodulatory } & $\begin{array}{l}\text { Inhibition of NF-KB associated with reduction of metastasis } \\
\text { in mice }\end{array}$ & Prostate cancer (PC-3M) & HUANG, et al. [38] \\
\hline & $\begin{array}{l}\text { Inhibition of NF-KB, protection of thymic cells to reactive } \\
\text { species of oxygen and tumor-induced TNF- } \alpha \text {-induced } \\
\text { apoptosis }\end{array}$ & $\begin{array}{l}\text { Renal carcinoma } \\
\text { (SK-RC-45 and SK-RC-26B) }\end{array}$ & $\begin{array}{l}\text { BHATTACHARYYA, et } \\
\text { al. [39] }\end{array}$ \\
\hline & increased production of TNF- $\alpha$, IL-2 and INF- $\nu$ & $\begin{array}{l}\text { Peripheral blood } \\
\text { mononuclear cells }\end{array}$ & YUE, et al. [7] \\
\hline & Inhibition of NF-kB associated with urokinase suppression & Lung Cancer (MCF-7) & ZONG, et al. [40] \\
\hline
\end{tabular}

Although the curcumin antitumor activity has been demonstrated to be important, in the same way the antitumor effect of turmeric-has also been observed both in the form of extracts [23,33,34] and essential oil [14].

Studies that evaluated curcumin-free turmeric observed suppression of benzo[a] pyrene-induced tumorigenesis in mice [33] and inhibition of 7,12-dimethylbenz[a] anthraceneinduced mammary tumorigenesis in rats [34]. Antiproliferative activity between curcumin and turmeric was compared in seven cancer cell lines. Both treatments presented similar amounts of curcumin, with a higher inhibition percentage for turmeric in all cell lines tested [23]. Therefore, other components than curcumin also contribute to the turmeric anticancer activities.

Curzerene is a sesquiterpene that presented dosedependent antiproliferative effect both in vitro and in vivo test 
[32]. The crude turmeric methanolic extract was evaluated by gas chromatography-mass spectrometry analysis (GC-MS). 50 compounds were detected, and the major compounds were ar-turmerone (20.50\%), $\beta$-sesquiphellandrene $(5.20 \%)$ and curcumenol (5.11\%) [15]. Recently evaluating turmeric ethanolic extract, four new sesquiterpenes were isolated [35].

Concerning the form of essential oil obtained from rhizomes, sesquiterpenes and oxygenated monoterpenes such as ar-Turmerone (33.2\%), $\alpha$-Turmerone (23.5\%) and $\beta$-Turmerone $(22.7 \%)$ were recorded using CG-MS and nuclear magnetic resonance (NMR) spectroscopy [14].

Likewise, using GC-MS to evaluate the essential oil, turmerone (35.9\%) was the majority component among the 23 compounds identified [36]. Complementarily, it should be noted that beyond the direct antineoplastic effects, the indirect effects such as immunomodulatory and antiinflammatory activities are relevant for tumor therapy (Table 3) [37-40].

Pre-clinical and clinical assays also demonstrated promising results (Table 4) [41-49]. But, although these tests were performed in mice, rats, dogs and other experimental animals, the development of research directly for veterinary medicine is scarce.

\section{The use of curcumin associated with other cancer therapies}

The combination of curcumin and cisplatin in the treatment of lung adenocarcinoma cells (A549) was favorable due to reversing tumor resistance. It was demonstrated (in vitro) the inhibition of factor induced by hypoxia-1 $(\mathrm{FIH}-\alpha)$ and reduction of $\mathrm{P}$-glycoprotein, these proteins are related to tumor resistance [50]. Furthermore, curcumin reduced neurotoxicity [51] and cisplastin nephrotoxicity [52].

The use associated with radiotherapy indicated that curcumin favored the action of radiation on colon cancer cells (HCT116 and HT29), increased sensitivity to this type of treatment by inhibiting nuclear factor kappa B (NF-KB) [47].

Promising results were found regards the effect of curcumin as a sensitizing agent to enhance the apoptotic potential of doxorubicin [31]. These researchers evaluated $I C_{50}$ dose $(5 \mathrm{nM})$ of doxorubicin and a lower dose $(2.5 \mathrm{nM})$.

Table 4: Pre-clinical and clinical studies with curcumin.

\begin{tabular}{|c|c|c|}
\hline Mechanisms of action/clinical action & Evaluation & References \\
\hline $\begin{array}{l}\text { Anti-inflammatory action: Decreased M1G levels from } 4.8 \text { F } 2.9 \text { adducts per } 107 \\
\text { nucleotides to } 2.0 \mathrm{~F} 1.8 \text { adducts per } 107 \text { nucleotides }\end{array}$ & $\begin{array}{l}\text { Human Patients } \\
\text { colorectal cancer }\end{array}$ & GARCEA, et al. [41] \\
\hline Phase I dose escalation: Toxicity at $8,000 \mathrm{mg} / \mathrm{d}$ & $\begin{array}{l}\text { Human Patients Breast } \\
\text { cancer }\end{array}$ & BAYET-ROBERT, et al. [42] \\
\hline $\begin{array}{l}\text { Association with PLGA Nanoparticles: } \\
\text { Improve bioavailability, increased solubility, higher release rate in intestinal juice, } \\
\text { enhanced absorption by improved permeability, inhibition of P-glycoprotein (P-gp)- } \\
\text { mediated efflux, and increased residence time in the intestinal cavity }\end{array}$ & Rats & XIE, et al. [43] \\
\hline $\begin{array}{l}\text { Association with of Liposomal Curcumin and its Metabolite Tetrahydrocurcumin: } \\
\text { Two-hour infusion levels were higher than eight-hour, and would be preferable } \\
\text { for liquid malignancies; however, eight-hour infusion would be preferable for solid } \\
\text { tumors. }\end{array}$ & Healthy Beagle Dogs & HELSON, et al. [44] \\
\hline $\begin{array}{l}\text { Association with Liposomal Curcumin and its Metabolite Tetrahydrocurcumin: } \\
\text { Facilitate distribution and elevated tissue concentrations of curcumin may inhibit or } \\
\text { saturate a putative reductase enzyme converting curcumin to THC }\end{array}$ & Healthy Beagle Dogs & MATABUDULm et al. [45] \\
\hline $\begin{array}{l}\text { Ameliorates Nephrotoxicity: Decrease levels of serum creatinine and urea, renal } \\
\text { malondialdehyde, NO, tumor necrosis factor- } \alpha \text { with a concurrent increase in renal } \\
\text { glutathione peroxidase and superoxide dismutase activities. } \\
\text { Reduced cyclooxygenase- } 2 \text { expression }\end{array}$ & $\begin{array}{l}\text { Methotrxate-induced } \\
\text { Nephrotoxicity Rats }\end{array}$ & MORSY, et al. [46] \\
\hline $\begin{array}{l}\text { Ameliorates Nephrotoxicity: Decrease serum concentrations TNF-alpha, renal TNF- } \\
\text { alpha, and decreased MCP-1 and ICAM-1 mRNA expression in kidney }\end{array}$ & $\begin{array}{l}\text { Cisplatin-induced } \\
\text { Nephrotoxicity Mice }\end{array}$ & SANDUR, et al. [47] \\
\hline Ameliorative Effect via Modulation of Inflammation, Oxidative Stress and Cell Death & & MENG, et al. [48] \\
\hline Apoptosis: Pathway PARP-, cleavage & $\begin{array}{l}\text { Pre-B Acute } \\
\text { Lymphoblastic } \\
\text { Leukemia Cell } \\
\text { Lines }\end{array}$ & MISHRA, et al. [31] \\
\hline $\begin{array}{l}\text { Apoptosis and Renoprotective effects: Inhibiting oxidative stress through regulation } \\
\text { of the AMPK and Nrf2/HO-1 signaling pathways, ameliorated RM-associated renal } \\
\text { injury }\end{array}$ & $\begin{array}{l}\text { Rhabdomyolysis- } \\
\text { induced rats }\end{array}$ & WU, et al. [49] \\
\hline
\end{tabular}


They found that both curcumin $(10 \mu \mathrm{M})$ and doxorubicin $(5$ $\mathrm{nM}$ ) induced apoptosis. However, the association of curcumin $(10 \mu \mathrm{M})$ with doxorubicin at a lower dose than its $I C_{50}(2.5$ $\mathrm{nM}$ ) was able to induce a higher level of apoptosis in Pre-B acute lymphoblastic leukemia cell lines. It was also observed dose dependence which suggests enhanced level of apoptosis when curcumin was supplemented with doxorubicin in cell culture.

Unfortunately, unfavorable associations may occur mainly if high doses of curcumin are used. It was verified that $6000 \mathrm{mg}$ of curcumin per day represent the limit dose capable to induce adverse effects. Higher doses $(8000 \mathrm{mg}$ daily) demonstrated to affect negatively the association with docetaxel in breast cancer [42]. The same association was studied in MCF7 and MDA-MB-231 breast cancer cells [29]. Curcumin at $10 \mathrm{mg} \mathrm{L}^{-1}$ in cotreatment with docetaxel induced modifications in glutathione and lipid metabolisms and glucose utilization. Some of these changes were biphasic
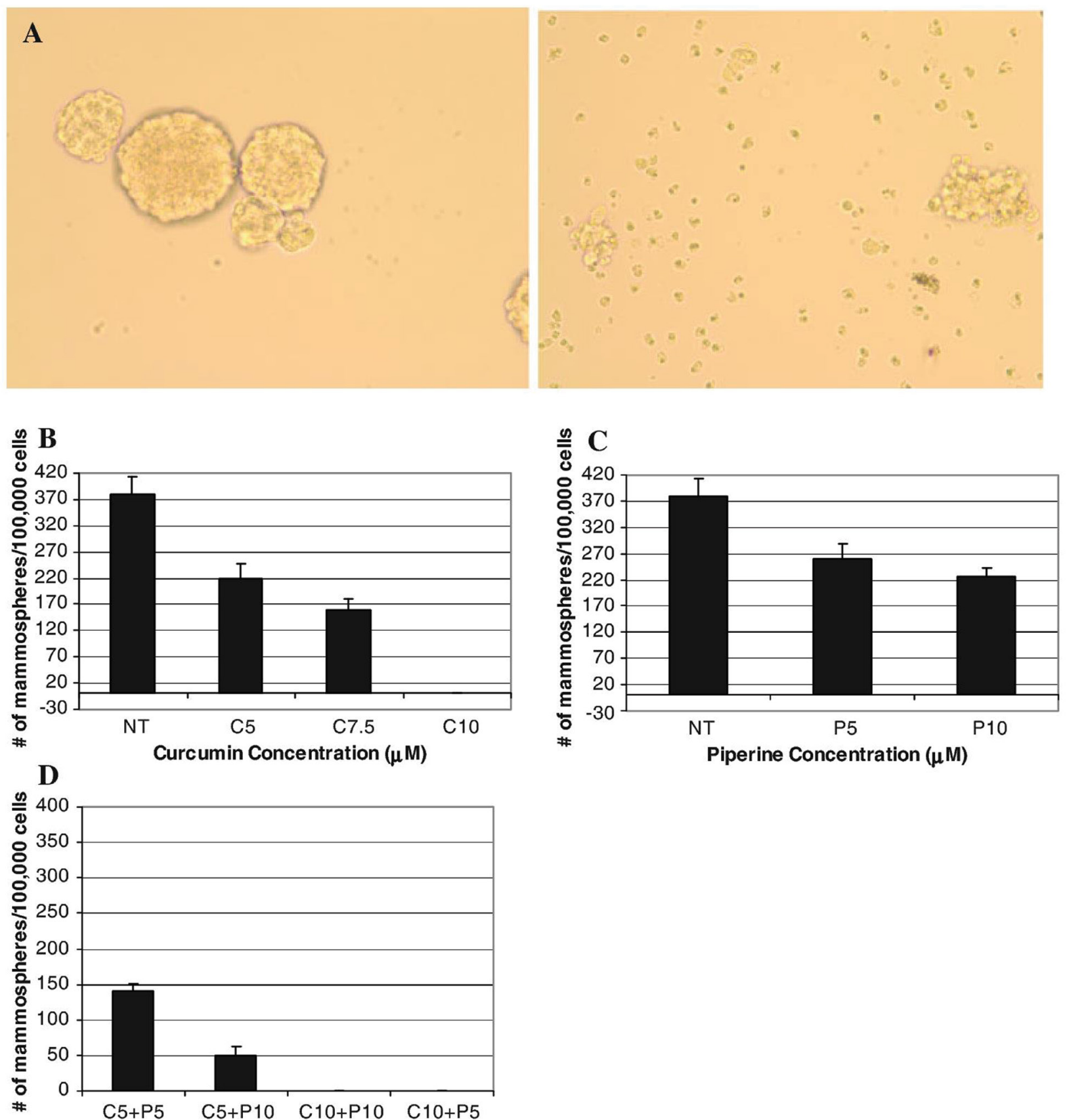

Curcumin and Piperine Concentration $(\mu \mathrm{M})$

Figure 1: A) Formation of primary multiple beads developed from normal human breast epithelial cells after treatment with $5 \mu \mathrm{M}$ curcumin (left image) and after treatment with piperine in the same dosage; B) Number of multiple spheres formation, formed from normal maternal undifferentiated epithelial cells in suspension culture with curcumin: $\mathrm{C} 5=5 \mu \mathrm{M}$ curcumin and $\mathrm{C} 10=10 \mu \mathrm{M}$ curcumin; C) Piperine treatment: P5 $=5 \mu \mathrm{M}$ and P10 $=10 \mu \mathrm{M}$; D) Treatment by the association curcumin + piperine. 
depending on the exposure duration to curcumin. Thus, the continuity of research involving the use of curcumin to cancer treatment is increasingly justified. Despite the various publications in recent years, the mechanisms of action involved still need to be best clarifying, mainly when combining two active principles [29].

The association between medicinal plants may also determine benefits to oncological treatment. Curcumin associated with Zingiber officinale promoted growth inhibition of prostate cancer and presented superior results when compared to both treatments $[53,54]$.

\section{Contribution of $\boldsymbol{C}$. longa in drug resistance control}

One of the major obstacles to the success of chemotherapy is the fact that some tumor cells develop multidrug pharmacological resistance (MDR) [55]. This process may be associated with overexpression of efflux pumps drug. P-glycoprotein is a drug efflux pump that is often found to be overexpressed in cases of acquired MDR. However, there are no P-glycoprotein inhibitors used in current clinical practice due to toxicity problems, drug interactions or pharmacokinetic problems. Thus, it has been carried out to search for natural products that can inhibit glycoproteins such as P-glycoprotein. Curcumin has shown important inhibition [56,57], emerging as a potential drug for the antitumor treatment response.

\section{Limiting factors of curcumin use: Bioavailability}

The high metabolism and low half-life of curcumin impairs its absorption when administered orally $[17,26,41,44,45,56]$. Therefore, in order to increase the solubility, bioavailability and anticancer activity of curcumin, associations with liposomes [17,26,44,45], nanoparticles $[43,58]$ and mainly piperine $[59,60]$ have been proposed.

The incorporation of curcumin into liposomes promoted growth inhibition of pancreatic carcinoma cell lines [17]. Similarly, liposomal curcumin suppresses the growth of head and neck squamous cell carcinoma (HNSCC) cell lines CAL27 and UM-SCC1 in vitro and in vivo tests [26]. Association between curcumin and liposomes was also evaluated from intravenous infusion of $10 \mathrm{mg} \mathrm{Kg}^{-1}$ in dogs [44]. These results indicated high plasma concentration of curcumin two hours after infusion, suggesting that this combination may be used in plasma cell and multiple myeloma tumors. This study was also performed by Matabudul, et al. [45] and after eight hours of infusion it was observed a significant increase of curcumin in lung, spleen and liver, demonstrating that the infusion time determined a better distribution of curcumin.

The nanoparticles associated with curcumin favor physical stability with maintenance of the cytotoxic activity of this curcuminoid in cancerous cells $[43,54,56]$.

By intravenous administration (2.5 $\mathrm{mg} \mathrm{Kg}^{-1}$ ) in mice, this association increased the bioavailability of curcumin in almost two times [56]. These authors also confirmed the antiproliferative activity in human chronic myeloid leukemia (KBM-5), human T-cell leukemia (Jurkat), prostate cancer cells (DU145), breast tumor (MDA-MB-231), esophageal cancer
(SEG-1) and colon cancer (line HCT116). It was demonstrated that curcumin loaded nanoparticulate formulation based on poly lactide-co-glycolide (PLGA) has enhanced cellular uptake and increased bioactivity in vitro and superior bioavailability in vivo over curcumin. They also observed increased cellular uptake of curcumin and inhibition of nuclear factor- kappa $B$ (NF-KB) expression level.

Rats submitted to curcumin with nanoparticles by the oral route demonstrated increased solubility and bioavailability in five to six times and had a longer half-life. The results showed that the effect in improving oral bioavailability of curcumin may be associated with improved water solubility, higher release rate in the intestinal juice, enhanced absorption by improved permeability, inhibition of P-glycoprotein-mediated efflux and increased residence time in the intestinal cavity [43].

The association of curcumin with piperine, a polyphenol isolated from black peppers, increased the curcumin oral bioavailability $[58,61]$. In order to determine the ability to modulate the self-renewal of normal and malignant breast cells, Kakarala, et al. $[58,61,62]$ examined multiple spheres formation trait and the expression of the breast stem cells with aldehyde marker dehydrogenase (ALDH) signaled by Wnt pathway. Both curcumin and piperine were able to inhibit the formation of the multiple beads, however, the addition of piperine to curcumin potentiated this reduction compared to the compounds used separately (Figure 1).

In addition, it is important to consider that some compounds of piperine may be able to determine some synergic action mechanism with turmeric. Genotoxicity was evaluated in hamsters induced by single dose $\left(30 \mathrm{mg} \mathrm{Kg}^{-1}\right)$ intraperitoneal injection of 7,12-dimethylbenz[a]anthracene. The curcumin association with piperine was able to potentiate its antigenotoxic effect, evidenced by the decrease of polychromatic erythrocytes and acrosomal aberrations $[61,62]$.

Considering the antitumoral effect of $\beta$-elemene derived from Curcuma wenyujin, it was synthesized five novel $\beta$-elements from the piperazine: 13-(3-methyl-1-piperazinyl)b-elemene (DX1), 13-(cis-3,5-dimethyl-1-piperazinyl)-b (DX2), 13-(4-isopropyl-1-piperazinyl)-b-eel (DX4) and 13-piperazinylb-element (DX5) [7]. These researchers reported that activation of caspase- 8 by these new $\beta$-elemene, piperazine derivatives, was correlated with the decrease of cellular FLICElike inhibitory protein (c-FLIP) levels and $\mathrm{H}_{2} \mathrm{O}_{2}$ production, which determined the activation of the apoptotic pathways mediated by mitochondria, suggesting the influence of a synergic action mechanism.

\section{Conclusion}

Turmeric anticancer activity was evidenced by antiproliferative, apoptotic and antimetastatic activities. Its use associated with nanoparticles, liposomes and mainly piperazine, promoted greater bioavailability of curcumin when administered orally, signaling a promising future. Additionally, the anti-inflammatory and immunomodulatory activities presented by curcumin represent an important 
adjuvant mechanism of control for neoplastic pathogenesis. Therefore, the results of in vitro and in vivo tests, and preclinical and clinical trials showed that $C$. longa presents evidence of prophylactic and curative effects in cancer treatment.

\section{Conflict of Interest}

The authors declare that they have no financial or personal relationships that may have inappropriately influenced them in writing this article.

\section{Acknowledgments}

We would like to thank the Araucária Foundation and National Council for Scientific and Technological Development (CNPq) for the financial support and scholarships granted.

\section{References}

1. Siegel RL, Miller KD, Jemal A (2016) Cancer statistics, 2016. CA Cancer J Clin 66: 7-30.

2. Tostes RA, Branco A, Cestari FK (2017) Retrospective study of canine cutaneous neoplasia. Archives of Veterinary Sciences 22 71-80.

3. Zavery B, Appleton L, Sandiford K, et al. (2013) Complementary and alternative medicine use amongst oncology patients attending a large cancer centre in England. Progress in Palliative Care 18: 89-93.

4. Hosseini A, Ghorbani A (2015) Cancer therapy with phytochemicals: Evidence from clinical studies. Avicenna J Phytomed 5: 84-97.

5. Damery S, Gratus C, Grieve R, et al. (2011) The use of herbal medicines by people with cancer: A cross-sectional survey. $\mathrm{Br} J$ Cancer 104: 927-933.

6. Chiu J, Yau T, Epstein RJ (2008) Complications of traditional Chinese/herbal medicines (TCM) - a guide for perplexed oncologists and other cancer caregivers. Supportive Care Cancer 17: 231-240.

7. Yue GGL, Chan BCL, Hon P, et al. (2010) Evaluation of in vitro antiproliferative and immunomodulatory activities of compounds isolated from Curcuma longa. Food Chem Toxicol 48: 2011-2020.

8. Wu SH, Hang LW, Yang JS, et al. (2010) Curcumin induces apoptosis in human non-small cell lung cancer $\mathrm{NCl}-\mathrm{H} 460$ cells through ER stress and caspase cascade - and mitochondriadependent pathways. Anticancer Res 30: 2125-2133.

9. Senft C, Polacin M, Priester M, et al. (2010) The nontoxic natural compound curcumin exerts anti-proliferative, anti-migratory, and anti-invasive properties against malignant gliomas. BMC Cancer 10: 1-8.

10. Bill MA, Bakan C, Benson DM, et al. (2009) Curcumin induces proapoptotic effects against human melanoma cells and modulates the cellular response to immunotherapeutic cytokines. Mol Cancer Ther 8: 2726-2735.

11. Ibrahim A, El-Meligy A, Lungu G, et al. (2011) Curcumin induces apoptosis in a murine mammary gland adenocarcinoma cell line through the mitochondrial pathway. Eur J Pharmacol 668: 127132.

12. Prakobwong S, Gupta SC, Kim JH, et al. (2011) Curcumin suppresses proliferation and induces apoptosis in human biliary cancer cells through modulation of multiple cell signaling pathways. Carcinogenesis 32: 1372-1380.
13. Song F, Zhang L, Yu HX, et al. (2012) The mechanism underlying proliferation-inhibitory and apoptosis-inducing effects of curcumin on papillary thyroid cancer cells. Food Chem 32: 43-50.

14. Santos Pasr, Avanço GB, Nerilo SB, et al. (2016) Assessment of cytotoxic activity of rosemary (Rosmarinus officinalis L.), turmeric (Curcuma longa L.), and ginger (Zingiber officinale R.) essential oils in cervical cancer cells (Hela). Scientific World Journal 2016: 9273078.

15. Abdel-Lateef E, Mahmoud F, Hammam O, et al. (2016) Bioactive chemical constituents of Curcuma longa L. rhizomes extract inhibit the growth of human hepatoma cell line (HepG2). Acta Pharm 66: 387-398.

16. Mou S, Zhou Z, He Y, et al. (2017) Curcumin inhibits cell proliferation and promotes apoptosis of laryngeal cancer cells through $\mathrm{Bcl}-2$ And $\mathrm{PI} 3 \mathrm{k} / \mathrm{Akt}$, and by upregulating mir-15a. Oncol Lett 14: 4937-4942.

17. Li L, Braiteh FS, Kurzrock R (2005) Liposome-encapsulated curcumin in vitro and in vivo effects on proliferation, apoptosis, signaling, and angiogenesis. Cancer 104: 1322-1331.

18. Lu W, Tinsley HN, Keeton A, et al. (2009) Suppression of Wnt/Bcatenin signaling inhibits prostate cancer cell proliferation. Eur J Pharmacol 602: 8-14.

19. Cai XZ, Wang J, Xiao-Dong L, et al. (2009) curcumin suppresses proliferation and invasion in human gastric cancer cells by downregulation of PAK ${ }_{1}$ activity and cyclin $\mathrm{D}_{1}$ expression. Cancer Bio Ther 8: 1360-1368.

20. Saha A, Kuzuhara T, Echigo N, et al. (2010) Apoptosis of human lung cancer cells by curcumin mediated through up-regulation of "Growth arrest and DNA damage inducible genes 45 And 153". Biological and Pharmaceutical Bulletin 33: 1291-1299.

21. Mudduluru G, George-William JN, Muppala S, et al. (2011) Curcumin regulates mir-21 expression and inhibits invasion and metastasis in colorectal cancer. Biosci Rep 31: 185-197.

22. Teiten M, Gaascht F, Cronauer M, et al. (2011) Anti-proliferative potential of curcumin in androgen dependent prostate cancer cells occurs through modulation of the wingless signaling pathway. Int J Oncol 38: 603-611.

23. Kim JH, Gupta SC, Park B, et al. (2011) Turmeric (Curcuma longa) inhibits inflammatory nuclear factor (Nf)-Kb and Nf-Kbregulated gene products and induces death receptors leading to suppressed proliferation, induced chemosensitization, and suppressed osteoclastogenesis. Mol Nutr Food Res 56: 454-465.

24. Tsai K, Lin JC, Yang SM, et al. (2012) Curcumin protects against uvb-induced skin cancers in skh-1 hairless mouse: Analysis of early molecular markers in carcinogenesis. Evid Based Complement and Alternat Med 2012: 1-11.

25. Li Y, Zhang J, Ma D, et al. (2012) Curcumin inhibits proliferation and invasion of osteosarcoma cells through inactivation of Notch-1 signaling. Febs J 279: 2247-2259.

26. Wang D, Veena MS, Stevenson K, et al. (2008) Liposomeencapsulated curcumin suppresses growth of head and neck squamous cell carcinoma in vitro and in xenografts through the inhibition of nuclear factor $\mathrm{kb}$ by an akt-independent pathway. Clin Cancer Res 14: 6228-6236.

27. Campos PS, Matte BF, Diel LF, et al. (2017) Low doses of curcuma longa modulates cell migration and cell-cell adhesion. Phytother Res 31: 1433-1440.

28. Jiang J, Jin $\mathrm{X}$, Zhang $\mathrm{H}$, et al. (2012) Identification of antitumor 
constituents in curcuminoids from curcuma longa I. based on the composition-activity relationship. J Pharm Biomed Anal 70: 664-670.

29. Bayet-Robert M, Morvan D (2013) Metabolomics reveals metabolic targets and biphasic responses in breast cancer cells treated by curcumin alone and in association with docetaxel. PLoS One 8: e57971.

30. Sankpal UT, Nagaraju GP, Gottipolu SR, et al. (2015) Combination of tolfenamic acid and curcumin induces colon cancer cell growth inhibition through modulating specific transcription factors and reactive oxygen species. Oncotarget 7: 3186-3200.

31. Mishra D, Singh S, Narayan G (2016) Curcumin induces apoptosis in pre-b acute lymphoblastic leukemia cell lines via parp-1 cleavage. Asian Pac J Cancer Prev 17: 3865-3869.

32. Wang Y, Li J, Guo J, et al. (2016) Cytotoxic and antitumor effects of curzerene from curcuma longa. Planta Med 83: 23-29.

33. Deshpande SS, Ingle AD, Maru GB (1997) Inhibitory effects of curcumin-free aqueous turmeric extract on benzo[a]pyreneinduced forestomach papillomas in mice. Cancer Lett 118: 79-85.

34. Deshpande SS, Ingle AD, Maru GB (1998) Chemopreventive efficacy of curcumin-free aqueous turmeric extract in 7,12-dimethylbenz[a]anthracene-induced rat mammary tumorigenesis. Cancer Lett 123: 35-40.

35. Wen J, Qiu T, Yan X, et al. (2017) Four novel bisabolane-type sesquiterpenes from curcuma longa. J Asian Nat Prod Res 20 928-933.

36. Oyemitan IA, Elusiyan CA, Onifade AO, et al. (2017) Neuropharmacological profile and chemical analysis of fresh rhizome essential oil of curcuma longa (turmeric) cultivated in Southwest Nigeria. Toxicol Rep 4: 391-398.

37. Basnet P, Skalko-Basnet N (2011) Curcumin: An antiinflammatory molecule from a curry spice on the path to cancer treatment. Molecules 16: 4567-4598.

38. Huang S, Pettaway CA, Uehara H, et al. (2001) Blockade of NfkappaB activity in human prostate cancer cells is associated with suppression of angiogenesis, invasion, and metastasis. Oncogene 20: 4188-4197.

39. Bhattacharyya S, Mandal D, Sen GS, et al. (2007) Tumor-induced oxidative stress perturbs nuclear factor-карраB activityaugmenting tumor necrosis factor-a-mediated t-cell death: Protection by curcumin. Cancer Res 67: 362-370.

40. Zong $\mathrm{H}$, Wang F, Fan $Q$, et al. (2011) Curcumin inhibits metastatic progression of breast cancer cell through suppression of urokinase-type plasminogen activator by $\mathrm{Nf}$-kappaB signaling pathways. Mol Biol Rep 39: 4803-4808.

41. Garcea G, Berry DP, Jones DJL, et al. (2005) Consumption of the putative chemopreventive agent curcumin by cancer patients: Assessment of curcumin levels in the colorectum and their pharmacodynamic consequences. Cancer Epidemiol Biomarkers Prev 14: 120-125.

42. Bayet-Robert M, Kwiatkowski F, Leheurteur M, et al. (2010) Phase I dose escalation trial of docetaxel plus curcumin in patients with advanced and metastatic breast cancer. Cancer Biol Ther 9: 8-14.

43. Xie $X$, Tao $Q$, Zou $Y$, et al. (2011) PLGA nanoparticles improve the oral bioavailability of curcumin in rats: Characterizations and mechanisms. J Agric Food Chem 59: 9280-9289.
44. Helson L, Bolger G, Majeed M, et al. (2012) Infusion pharmacokinetics of lipocurc ${ }^{\mathrm{TM}}$ (Liposomal curcumin) and its metabolite tetrahydrocurcumin in beagle dogs. Anticancer Res 32: 4365-4370.

45. Matabudul D, Pucaj K, Bolger G, et al. (2012) Tissue distribution of (Lipocurc ${ }^{\mathrm{TM}}$ ) liposomal curcumin and tetrahydrocurcumin following two- and eight-hour infusions in beagle dogs. Anticancer Res 32: 4359-4364.

46. Morsy MA, Ibrahim SA, Amin EF, et al. (2013) Curcumin ameliorates methotrexate-induced nephrotoxicity in rats. Adv Pharmacol Sci 2013: 387071.

47. Sandur SK, Deorukhkar A, Pandey MK, et al. (2009) Curcumin modulates the radiosensitivity of colorectal cancer cells by suppressing constitutive and inducible Nf-kb activity. Int J Radiat Oncol Biol Phys 75: 534-542.

48. Meng H, Fu G, Shen J, et al. (2017) Ameliorative effect of daidzein on cisplatin-induced nephrotoxicity in mice via modulation of inflammation, oxidative stress, and cell death. Oxid Med Cell Longev 2017: 3140680.

49. Wu J, Pan X, Fu H, et al. (2017) Effect of curcumin on glycerolinduced acute kidney injury in rats. Sci Rep 7: 10114.

50. Ye M, Zhao Y, Li Y, et al. (2012) Curcumin reverses cis-platin resistance and promotes human lung adenocarcinoma A549/ DDP cell apoptosis through Hif- $1 \alpha$ and caspase- 3 mechanisms. phytomedicine 19: 779-787.

51. Mendonça LM, Machado CS, Teixeira CCC, et al. (2013) Curcumin reduces cisplatin-induced neurotoxicity in NGF-differentiated PC12 cells. Neurotoxicology 34: 205-211.

52. Ueki M, Ueno M, Morishita J, et al. (2013) Curcumin ameliorates cisplatin-induced nephrotoxicity by inhibiting renal inflammation in mice. J Biosci Bioeng 115: 547-551.

53. Kurapati KR, Samikkannu T, Kadiyala DB, et al. (2012) Combinatorial cytotoxic effects of curcuma longa and Zingiber officinale on the $\mathrm{PC}-3 \mathrm{~m}$ prostate cancer cell line. J Basic Clin Physiol Pharmacol 23: 139-146.

54. Yang QQ, Cheng LZ, Zhang T,et al. (2020) Phenolic profiles, antioxidant, and antiproliferative activities of turmeric (Curcuma longa). Industrial Crops and Products 152: 112561.

55. Huber PC, Maruiama CH, Almeida WP (2010) Glicoproteína-P, resistência a múltiplas drogas ( $\mathrm{mdr}$ ) e relação estrutura-atividade de moduladores. Quím Nova 33: 2148-2154.

56. Neerati P, Sudhakar YA, Kanwar J (2013) Curcumin regulates colon cancer by inhibiting $\mathrm{p}$-glycoprotein in in-situ cancerous colon perfusion rat model. J Cancer Sci Ther 5: 313-319.

57. Lopes-Rodrigues V, Oliveira A, Correia-Da-Silva M, et al. (2017) A novel curcumin derivative which inhibits p-glycoprotein, arrests cell cycle and induces apoptosis in multidrug resistance cells. Bioorg Med Chem 25: 581-596.

58. Anand P, Nair HB, Sung B, et al. (2010) Design of curcumin loaded PLGA nanoparticles formulation with enhanced cellular uptake, and increased bioactivity in vitro and superior bioavailability in vivo. Biochem Pharmacol 79: 330-338.

59. Shaikh J, Ankola DD, Beniwal V, et al. (2009) Nanoparticle encapsulation improves oral bioavailability of curcumin by at least 9-fold when compared to curcumin administered with piperine as absorption enhancer. Eur J Pharm Sci 37: 223-230.

60. Kakarala M, Brenner DE, Korkaya H, et al. (2009) Targeting breast 
Citation: Peixoto ECTDM, Silva FR, Figueiredo A, et al. (2022) Efficacy and Safety of Curcuma longa L: Relevant Results for Cancer Treatment. J Hortic Sci Res 5(1):175-183

stem cells with the cancer preventive compounds curcumin and piperine. Breast Cancer Res Treat 122: 777-785.

61. Balakrishnan S, Vellaichamy L, Menon VP, et al. (2008) Antigenotoxic effects of curcumin and piperine alone or in combination against 7,12-dimethylbenz(a)anthracene induced genotoxicity in Bone marrow of golden syrian hamsters. Toxicol Mech Methods 18: 691-696.

62. Paradkar PH, Juvekar AS, Barkume MS, et al. (2021) In vitro and In vivo evaluation of a standardized haridra (Curcuma longa linn) formulation in cervical cancer. Journal of Ayurveda and Integrative Medicine 12: 616-622.

DOI: $10.36959 / 745 / 413$ 